\title{
The Need for Basic Medical Science Knowledge in Clinical Setting: Perspective of Resident Physicians
}

\author{
Klinik Ortamda Temel Tıp Bilimi Bilgisine Duyulan Ihtiyaç: \\ Erken Klinisyenlerin Bakıș Açısı
}

\section{Oktay KAYA}

Trakya University, Faculty of Medicine, Departments of Physiology, Edirne, Turkey

ORCID ID: Oktay Kaya 0000-0001-9639-8022

Cite this article as: Kaya O. The Need for Basic Medical Science Knowledge in Clinical Setting: Perspective of Resident Physicians. Med J West Black Sea. 2021;5(2):193-197.

Corresponding Author

Oktay Kaya

E-mail

droktaykaya@gmail.com
Received

07.01.2021

Revision

20.02.2021

Accepted

24.02.2021

\begin{abstract}
Aim: The aim of the study was to evaluate the opinions of research assistants working in clinical departments about basic medical sciences education and their tendency in career choices.

Material and Methods: The study was conducted on 110 research assistants working in the internal and surgical medical sciences. The data were obtained by using a questionnaire developed by the researcher and based on volunteering.

Results: When the study group was asked about the field of basic medical sciences they used most during their professional lives, physiology ranked first with $36.8 \%(n=32) .73 .2 \%$ of the participants responded to the proposition that I need basic medical science knowdelge in my specialty. $43.1 \%$ of the participants agreed with the statement that I absolutely did not want to do specialty training in the field of basic medical sciences.

Conclusion: It was thought that basic medical sciences curriculum should be structured according to the needs of clinical sciences. The positive opinion on basic medical education does not reflect on career choice.
\end{abstract}

Keywords: Basic medical sciences, Medical education, Integration, Career choice

\section{ÖZ}

Amaç: Çalışmanın amacı, klinik bölümlerde çalışan araştırma görevlilerinin temel tıp bilimleri eğitimi hakkındaki görüşlerini ve kariyer tercihlerindeki eğilimlerini değerlendirmektir.

Gereç ve Yöntemler: Çalışma dahili ve cerrahi tıp bilimlerinde çalışan 110 araştırma görevlisi üzerinde gerçekleştirildi. Veriler, araştırmacı tarafından geliştirilen ve gönüllülüğe dayalı bir anket kullanılarak elde edildi.

Bulgular: Çalışma grubuna meslek hayatları sırasında en fazla faydalandıkları temel tıp bilimleri alanı sorulduğunda fizyoloji \%36.8 $(n=32)$ ile ilk sırada yer aldı. Temel tıp bilimleri eğitimine uzmanlık alanımda ihtiyaç duyuyorum" önermesine katılımcıların \% 73,2'si katılıyorum cevabını verdi. Temel tıp bilimleri alanında uzmanlık eğitimi yapmayı kesinlikle istemedim ifadesine katılımcıların \% 43,1'i katılmıştır.

Sonuç: Temel tıp bilimleri müfredatının klinik bilimlerin intiyaçlarına göre yapılandırılması gerektiği düşünülmüştür. Temel tıp bilimleri eğitimine olan olumlu bakış kariyer seçimine yansımamaktadır.

Anahtar Sözcükler: Temel tıp bilimleri, Tıp eğitimi, Entegrasyon, Kariyer seçimi 


\section{INTRODUCTION}

The aim of medical education is defined as 'to train physicians who will improve health for everyone' (1). The foundation of medical education is laid with the basic medical sciences courses in the first two years of undergraduate education. The Flexner report, published in 1910, formed the basis for significant changes in medical education. The Flexner report suggested that medical education without a solid scientific foundation would be incomplete and that students should be educated in basic sciences before starting clinical education. After the report, a 4-year traditional medicine curriculum was designed, including 2 years in basic sciences and 2 years clinical sciences. The Flexner 2 report, published a century later, suggested integrating basic sciences with clinical sciences and teaching basic sciences in the context of clinical facts $(2,3)$.

Accreditation bodies have acknowledged the roles of basic science in medical education and training that support clinical reasoning skills, analysis of medical and surgical practices, and analysis of processes to improve health care (4). Research results show that the content of basic science remains important for clinical applications and basic science teaching should be carried out throughout the entire medical education and in an integrated manner with clinical practices $(4,5)$.

It is of great importance to determine the goals and objectives of undergraduate medical education, to measure competencies and proficiencies as well as knowledge, and to develop an education plan in accordance with these criteria. It is essential to evaluate the graduate students' feedback in terms of eliminating the deficiencies of medical education, determining new strategies, and ultimately increasing the quality of the trained medical doctor (6).

In the study of Kalaycıoğlu DB, it was reported that only 6.4 $\%$ of 18308 physicians who settled in a specialty area with the result of Medical Specialization Examinations preferred a department in the field of basic medical sciences. It has been reported that many factors such as the conditions and durations of specialization training, performance criteria, perceived prestige and earnings of the branches may have led to this result (7).

The purpose of this study is to determine the views of clinical research assistants at Trakya University Faculty of Medicine about basic medical sciences education, to evaluate the tendency towards basic medical science specialties in career choices.

\section{MATERIALS and METHODS}

Ethical approval was obtained prior to this cross-sectional descriptive research (Trakya University Medical Faculty Scientific Investigations Evaluation Committee 2019/96, 25.02.2019). The sample size was calculated with $5 \%$ mar- gin of error, $80 \%$ power and 0.3 effect size. The calculated sample size was 108 participant. Thus, we terminated data collection after obtaining 110 participant. All residents working at our hospital were invited to participate via printed handouts and notices posted on walls. Among residents working in internal and surgical medical sciences, 110 respondents were completed the questionnaire between March 2019 to May 2019. The data were obtained through face-to-face interview method using a voluntary questionnaire consisting of 33 questions developed by the researcher. Participants were asked not to write their name and surname on the questionnaire. The questionnaire included questions about the demographic data of the research assistants participating in the study, their educational background, the reasons for choosing the medical faculty and their specialty, their thoughts about the basic medical sciences education they received, and the factors that determine their undergraduate and graduate education preferences.

The data were analyzed and interpreted on SPSS 22.0 for Windows. Chi-square test was used in the analysis of categorical variables. Results are given as percentage and frequency for categorical values. Normal distribution for continuous variables was evaluated with kurtosis-skewness values and Shapiro-Wilk test. Descriptive statistics were used for continuous variables. Quantitative values were given as Mean \pm Standard deviation (SD). Statistical significance was adjusted to a $p$ value lower than 0.05 .

\section{RESULTS}

The average age of the research assistants participating in the study is $27.90 \pm 2.42$. Gender distribution analysis of the participants showed higher number of female participants [Male versus female participants n (\%), 44 (41.9\%) versus $61(58.1 \%)$ ]. Considering the medical science fields that the participants specialized in, $90(83.3 \%)$ were continuing their residency training in internal medical sciences and $18(16.7 \%)$ were in the field of surgical medical sciences. Half of the participants [54 (50\%)] stated that they received medical school education with the classical system, while those who gave the integrated system, problem based learning (PBL)-weighted, and other answers were $44(40.7 \%), 9(8.3 \%)$ and $1(0.9 \%)$, respectively. Data on the gender and educational backgrounds of the participants are given in Table 1. Participants indicated the field of basic medical sciences, which they most benefited from in their specialty, as physiology. All the answers given to the questionnaire questions are shown in Table 2. In the Likert-type questionnaire in which participants' opinions on basic medical sciences education are questioned, a generally positive view has been recorded. The percentages of all questions and answers are given in Table 3. Finally, we found no significant relationship between the need for basic medical sciences knowledge in professional life and career choice (Chi-square $p=0.11$ ). 
Table 1: Data on participants' gender and educational background

\begin{tabular}{|c|c|c|}
\hline & $\begin{array}{l}\text { Number } \\
\text { (n) }\end{array}$ & $\begin{array}{c}\text { Percent } \\
(\%)\end{array}$ \\
\hline \multicolumn{3}{|l|}{ Gender } \\
\hline Female & 64 & 58.1 \\
\hline Male & 46 & 41.9 \\
\hline \multicolumn{3}{|l|}{ Medical specialty } \\
\hline Internal medical sciences & 91 & 82.7 \\
\hline Surgical medical sciences & 19 & 17.3 \\
\hline \multicolumn{3}{|l|}{$\begin{array}{l}\text { The reason for choosing medical } \\
\text { school }^{*}\end{array}$} \\
\hline My choice & 73 & 3.7 \\
\hline My family directed & 33 & 16.6 \\
\hline Ease of finding a Job & 37 & 18.6 \\
\hline Social status & 21 & 10.6 \\
\hline Promise of good income & 16 & 8.0 \\
\hline $\begin{array}{l}\text { My score was enough for the faculty of } \\
\text { medicine }\end{array}$ & 16 & 8.0 \\
\hline Other & 3 & 1.5 \\
\hline \multicolumn{3}{|l|}{$\begin{array}{l}\text { The reason for choosing your } \\
\text { specialty }\end{array}$} \\
\hline My choice & 93 & 61.2 \\
\hline My family directed & 6 & 3.9 \\
\hline Social status & 8 & 5.3 \\
\hline Promise of good income & 5 & 3.3 \\
\hline $\begin{array}{l}\text { My Score was enough for this } \\
\text { specialization area }\end{array}$ & 30 & 19.7 \\
\hline Other & 10 & 6.6 \\
\hline \multicolumn{3}{|l|}{ Undergraduate Education System } \\
\hline Classical & 54 & 49.1 \\
\hline Integrated & 44 & 40 \\
\hline Problem based & 11 & 10 \\
\hline Other & 1 & 0.9 \\
\hline
\end{tabular}

*Participants were able to mark more than one option.

\section{DISCUSSION}

The main finding of the study is that there was no significant relationship between the need for basic medical sciences knowledge in professional life and career choice.

A study conducted in Iran revealed that basic science courses have little to do with the clinic; therefore, cannot prepare students for the clinic. Anatomy, physiology, and pathology are the courses that are considered to be most useful when preparing students for clinical work (8). A cross-sectional study conducted in Saudi Arabia reported that 21\%, 19\%, and $50 \%$ of students were able to recall anatomy, biochemistry, and physiology during their clinical years, respectively (9). In our study, $79(73.2 \%)$ of the participants scored 'agree' to "I need for basic medical sciences knowledge in my specialty" statement. When the study group was asked about the field of basic medical sciences that they benefited most during their professional life; physiology got the first rank by receiving $32(29.4 \%)$ of the answers. Subsequently, microbiology 23 (21.1\%), anatomy 19 (17.4\%), biochemistry $13(11.9 \%)$, histology and embryology $2(1.8 \%)$ and biostatistics $2(1.8 \%)$ courses followed physiology with

Table 2: Data on the basic medical science that the participants most benefit from in their specialty

\begin{tabular}{lcc}
\hline $\begin{array}{l}\text { What is the basic medical science } \\
\text { field you use most in your } \\
\text { specialization? }\end{array}$ & $\begin{array}{c}\text { Number } \\
\text { ( } \mathbf{n})\end{array}$ & $\begin{array}{c}\text { Percent } \\
\text { (\%) }\end{array}$ \\
\hline Physiology & 32 & 36.8 \\
Microbiology & 23 & 25.3 \\
Anatomy & 19 & 20.9 \\
Biochemistry & 13 & 14.6 \\
Histology & 2 & 2.2 \\
Biostatistics & 2 & 2.2 \\
\hline
\end{tabular}

Table 3: Percentage of Participants Scoring Agree on Statements related to Basic Medical Sciences Education

\begin{tabular}{|c|c|c|c|}
\hline Statements & Agree (\%) & I'm ambivalent (\%) & I do not agree (\%) \\
\hline I need for basic medical sciences knowledge in my specialty & 73.2 & 18.5 & 8.4 \\
\hline Must have basic medical education integration into my specialty education & 60.6 & 28.4 & 11 \\
\hline $\begin{array}{l}\text { The number of faculty members in basic medical sciences were sufficient } \\
\text { during the undergraduate period }\end{array}$ & 64.2 & 17 & 18.9 \\
\hline $\begin{array}{l}\text { Basic medical sciences laboratory facilities were sufficient during the } \\
\text { undergraduate period }\end{array}$ & 51.3 & 20.2 & 28.4 \\
\hline $\begin{array}{l}\text { A comprehensive understanding of basic sciences is essential for the } \\
\text { future of medicine as a profession. }\end{array}$ & 91.6 & 5.6 & 2.8 \\
\hline $\begin{array}{l}\text { If I could start medical school again, I would pay more attention to basic } \\
\text { medical science education }\end{array}$ & 71 & 16.8 & 12.2 \\
\hline $\begin{array}{l}\text { The time spent on teaching basic sciences should be reduced to the time } \\
\text { allocated for clinical sciences }\end{array}$ & 21.3 & 30.6 & 48.1 \\
\hline $\begin{array}{l}\text { Basic sciences should be integrated with clinical sciences and basic } \\
\text { sciences should be taught in the context of clinical facts }\end{array}$ & 90.5 & 3.8 & 5.6 \\
\hline I definitely did not want to study a specialty in basic medical sciences & 43.1 & 23.9 & 33 \\
\hline
\end{tabular}


their respective percentages. Physiology is a fundamental subject for medical education. It is associated with many disciplines such as anatomy, histology, biochemistry, biophysics, cell biology, clinical medicine and pharmacology, and there are no strict boundaries between them. Therefore, the high percentage of physiology given as an answer is not surprising. It should also be taken into consideration that the fact that the participants are mostly from internal medical sciences may be effective in the low percentage of anatomy.

In our study, 96 (90.5\%) of the participants scored 'agree' to "Basic sciences should be integrated with clinical sciences and basic sciences should be taught in the context of clinical facts" statement. 83 (76.1\%) of the participants scored 'agree' to "Students can learn basic sciences better when they participate in the clinical environment simultaneously" statement. The early years of medical education are considerably essential for students to recognize their future roles and develop appropriate attitudes. Regarding the evaluation of the developments in the medical curriculum, it is found out that more and more importance is given to the integration of basic medical sciences education and clinical stages. In many medical faculties, vertical and horizontal integration practices are included in the early years of the curriculum to introduce preclinical medical students to important clinical topics. It is believed that the introduction of early clinical exposure programs in the first years of the medical curriculum facilitates the transition of medical students to the clinical stage, increases their motivation, makes them more aware of the role of basic sciences in medical practice, and increases their self-confidence in patient encounters (10).

Factors such as demographic characteristics, lifestyle preferences, expected income, pre-clinical and clinical experiences, role models and alternative career opportunities determine the career choices of medical students (11). Researches show that among the graduates of medical faculties, the number of people seeking graduate education in basic science fields (anatomy, biochemistry, microbiology, physiology and pharmacology) is rapidly decreasing. It has been identified that the main reasons for this situation are the desire to become a clinician and concerns about salary $(12,13)$. In the study of Çetkin et al., it is determined that only $6.5 \%$ of medical students wanted to specialize in basic medical sciences. $41.8 \%$ of the students answered "Which field would you choose if you had chosen Basic Medical Sciences even if your preference was not Basic Medical Sciences?" question as physiology (6). In our study, 47 (43.1\%) of the participants agreed with the statement that I definitely did not want to do specialty training in the field of Basic medical sciences.

As a result of this study, it is surmised that approximately $79(73 \%)$ of those who have chosen clinical branches need basic science knowledge; for this reason, the basic science curriculum should be structured according to this need and the tendency to gradually reduce the time allocated to basic sciences in medical education should be abandoned. It is also deduced that the reasons behind why medical faculty graduates did not choose basic sciences although it was considered as an option (approximately 57\%) should be investigated and necessary economic improvements should be made in order to increase preference in basic sciences to build our country's future in science.

\section{Acknowledgment}

None.

\section{Author Contrubitons}

Planning the study, reviewing the literature, methodology, analysis and editing, writing: Oktay Kaya.

\section{Conflicts of Interest}

There is not a conflict of interest.

\section{Financial Support}

There is not a financial support.

\section{Ethical Approval}

Ethical approval was obtained prior to this cross-sectional descriptive research (Trakya University Medical Faculty Scientific Investigations Evaluation Committee 2019/96, 25.02.2019).

\section{Peer Review Process}

A Blind peer review process was implemented

\section{REFERENCES}

1. The Edınburgh Declaratıon. World Conference on Medical Education of the World Federation for Medical Education, August 7th-12th 1988, Edinburgh, Scotland.

2. Flexner A. Medical education in the United States and Canada. From the Carnegie Foundation for the Advancement of Teaching, Bulletin Number Four, 1910. Bull World Health Organ 2002;80(7):594-602.

3. Badyal DK, Singh T. Teaching of the basic sciences in medicine: Changing trends. Natl Med J India 2015;28(3):137-140.

4. Grande JP. Training of physicians for the twenty-first century: Role of the basic sciences. Med Teach 2009;31(9):802-806.

5. Finnerty EP, Chauvin S, Bonaminio G, Andrews M, Carroll RG, Pangaro LN. Flexner revisited: The role and value of the basic sciences in medical education. Acad Med 2010;85(2):349-355.

6. Çetkin M, Turhan B, Bahşi I, Kervancıoğlu P. Tıp fakültesi öğrencilerinin anatomi eğitimi hakkındaki düşünceleri. Gaziantep Med J 2016;22(2):82-88.

7. Kalaycioglu B. 1987'Den 2017'ye hekimlerin uzmanlık alanı tercih değişimleri. Tıp Eğitimi Dünyası 2020;19(59):158-171. 
8. Entwistle $\mathrm{N}$, Tait $\mathrm{H}$, McCune V. Patterns of response to an approach to studying inventory across contrasting groups and contexts. Eur J Psychol Educ 2000;15(1):33-48.

9. Miller GE. An inquiry into medical teaching. J Med Educ 1962;37:185-191.

10. Khabaz Mafinejad M, Mirzazadeh A, Peiman S, Khajavirad N, Mirabdolhagh Hazaveh M, Edalatifard M, Allameh SF, Naderi N, Foroumandi M, Afshari A, Asghari F. Medical students attitudes towards early clinical exposure in Iran. Int J Med Educ 2016;7:195-199.
11. Kumar R, Dhaliwal U. Career choices of undergraduate medical students. Natl Med J India 2011;24(3):166-169.

12. Getu A, Tenaw B, Yeshaw Y. Basic Science courses in the eyes of medical Students during their clinical study years at University of Gondar. International Journal of Biomedical and Advance Research 2019;10(10): e5275

13. Ahmed SMM, Majumdar AA, Karim R, Rahman S, Rahman N. Career choices in preventive and social medicine and other non-clinical specialties among medical students: Bangladesh perspective. South East Asia Journal of Public Health 2011;1:64-67. 